\title{
The Pseudoautosomal Region and Sex Chromosome Aneuploidies in Domestic Species
}

\author{
T. Raudsepp P.J. Das F. Avila B.P. Chowdhary \\ Department of Veterinary Integrative Biosciences, College of Veterinary Medicine and Biomedical Sciences, \\ Texas A\&M University, College Station, Tex., USA
}

\section{Key Words}

Aneuploidy • Domestic species • Pseudoautosomal region •

Sex chromosomes $\cdot \mathrm{X}$-monosomy $\cdot \mathrm{X}$-trisomy

\begin{abstract}
The pseudoautosomal region (PAR) is a unique and specialized segment on the mammalian sex chromosomes with known functions in male meiosis and fertility. Detailed molecular studies of the region in human and mouse show dramatic differences between the 2 PARs. Recent mapping efforts in horse, dog/cat, cattle/ruminants, pig and alpaca indicate that the PAR also varies in size and gene content between other species. Given that PAR genes escape $\mathrm{X}$ inactivation, these differences might critically affect the genetic consequences, such as embryonic survival and postnatal phenotypes of sex chromosome aneuploidies. The aim of this review is to combine the available information about the organization of the PAR in domestic species with the cytogenetic data on sex chromosome aneuploidies. We show that viable XO individuals are relatively frequently found in species with small PARs, such as horses, humans and mice but are rare or absent in species in which the PAR is substantially larger, like in cattle/ruminants, dogs, pigs, and alpacas. No similar correlation can be detected between the PAR size and the $\mathrm{X}$ chromosome trisomy in different species. Recent
\end{abstract}

evidence about the likely involvement of PAR genes in placenta formation, early embryonic development and genomic imprinting are presented.

Copyright $\odot 2011$ S. Karger AG, Basel
The pseudoautosomal region (PAR) is a short region of sequence homology between the sex chromosomes and is involved in sex chromosome pairing, recombination and segregation in meiosis of the heterogametic sex. The region has been found in many plant and animal species, including mammals [Charlesworth et al., 2005; Ming and Moore, 2007].

The mammalian PAR was discovered almost 80 years ago through studies of male meiosis in rats, where a synaptonemal complex between the $\mathrm{X}$ and $\mathrm{Y}$ was detected [Koller and Darlington, 1934]. Similar structures were soon found between the terminal ends of the $\mathrm{X}$ and $\mathrm{Y}$ chromosomes in several other eutherian species [Pathak and Elder, 1980], but not in marsupials [Sharp, 1982]. These observations have later been validated through detailed molecular genetic studies both in eutherian [Martin, 2006; Oliver-Bonet et al., 2006; Kauppi et al., 2011] and marsupial [Page et al., 2005, 2006] mammals.

Whole or partial genome sequence data are available for almost all main domestic species - alpaca, cat, cat-

\section{KARGER}

Fax +41613061234 E-Mail karger@karger.ch www.karger.com
(C) 2011 S. Karger AG, Basel

$1661-5425 / 12 / 0063-0072 \$ 38.00 / 0$

Accessible online at:

www.karger.com/sxd
Terje Raudsepp

Molecular Cytogenetics Laboratory, Room 314B Bldg. 1197

Department of Veterinary Integrative Biosciences, Texas A\&M University

College Station, TX 77843 (USA)

Tel. +1 979862 2879, E-Mail traudsepp@cvm.tamu.edu 
tle, dog, horse, pig, and rabbit (Ensembl: http:// www.ensembl.org/index.html; UCSC: http://genome.ucsc. edu/). For a few species, such as dog [Lindblad-Toh et al., 2005], cattle [Bovine Genome Sequencing and Analysis Consortium et al., 2009] and horse [Wade et al., 2009], annotated sequence draft assemblies have been published, while the data for the remaining species are composed of partially annotated sequence scaffolds. The sequence information is supported, validated and chromosomally anchored by high-resolution whole genome linkage, radiation hybrid and/or cytogenetic maps which are available for most of the domestic species, viz., cat [Davis et al., 2009], dog [Breen et al., 2004], horse [Raudsepp et al., 2008], cattle [Everts-van der Wind et al., 2004], pig [Humphray et al., 2007], and rabbit [Chantry-Darmon et al., 2006]. Despite these outstanding achievements, information about the PAR remains scarce. In most sequence assemblies, the region is missing or represented only partially. Furthermore, most animal genome sequencing projects have used DNA from female individuals, thus obtaining diploid data for the $\mathrm{X}$ chromosome, but no sequences for the $\mathrm{Y}$. Thus, even though map data are available for the $\mathrm{X}$ chromosome, lack of information for the $\mathrm{Y}$ sets limitations to properly demarcate the PAR. Despite these difficulties, recent mapping efforts indicate that the PAR varies in size and gene content between eutherian species [Raudsepp and Chowdhary, 2008; Van Laere et al., 2008; Young et al., 2008; Das et al., 2009]. Given that PAR genes escape $\mathrm{X}$ inactivation [Bondy and Cheng, 2009], these differences might critically influence the genetic effects caused by changes in sex chromosome numbers. Therefore, the aim of this review is to discuss the possible association between the organization of the PAR and the occurrence and phenotypic implications of sex chromosome aneuploidies in domestic species. We will first summarize the knowledge about the human and mouse PARs because these are the only mammalian PARs that have been studied in detail. Thereafter, we will focus on the PARs of the domestic species and discuss the available information in conjunction with the cytogenetic data on sex chromosome aneuploidies. Possible functions of the PAR genes in mammalian biology will be discussed.

\section{Specific Features of the Mammalian Pseudoautosomal Region}

The PAR is a unique region of true sequence homology (98-100\%) between the eutherian X and Y chromosomes [Skaletsky et al., 2003; Galtier, 2004; Ross et al.,

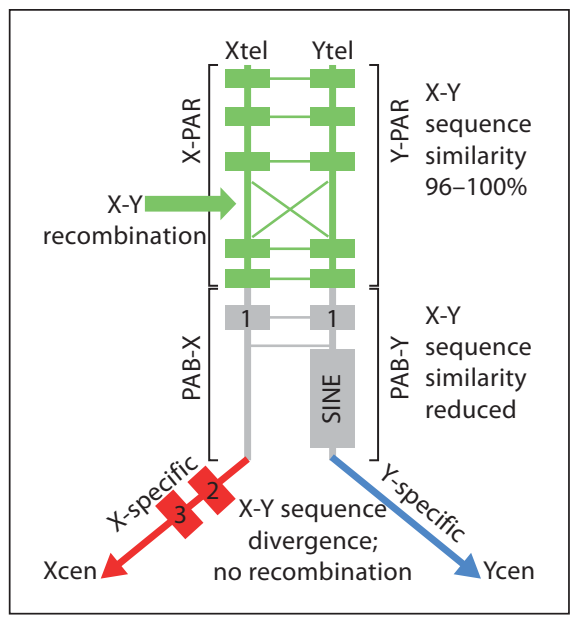

Fig. 1. A schematic illustrating the most characteristic structural features of the mammalian PAR. The PAR is shown in green, the $\mathrm{PAB}$ in grey, the $\mathrm{X}$ chromosome in red and the $\mathrm{Y}$ chromosome in blue colors; horizontal lines between the X and Y chromosomes demarcate sequence homology; crossed lines show a recombination site; filled rectangles stand for $\mathrm{X}-\mathrm{Y}$ homologous genes; filled rectangles with numbers - 1, 2, 3- demarcate the three exons of one gene: exon 1 is located in the PAB and is present on both sex chromosomes, while exons 2 and 3 are present only on the $\mathrm{X}$ chromosome; a SINE element has been transposed into the PAB-Y suppressing the X-Y recombination; Xtel and Ytel, and Xcen and Ycen demarcate telomeric and centromeric regions of the sex chromosomes, respectively. The figure does not represent the PAR of any particular species.

2005; Blaschke and Rappold, 2006; Mangs and Morris, 2007; Flaquer et al., 2008]. The physical domain of the PAR lies between the terminal ends of the sex chromosomes and the pseudoautosomal boundary (PAB) (fig. 1) - a border across which the sequence homology between the $\mathrm{X}$ and the $\mathrm{Y}$ chromosomes decreases, recombination ceases and regions specific to individual sex chromosomes begin [Galtier, 2004; Ross et al., 2005]. The $\mathrm{PAB}$ is typically demarcated by the insertion of transposable elements, like SINEs, which initiate the suppression of X-Y recombination [Ellis et al., 1989; Perry and Ashworth, 1999; Van Laere et al., 2008]. Also, most of the mammalian PABs studied so far are spanned by a gene which is truncated on one of the sex chromosomes [Ellis et al., 1989; Perry and Ashworth, 1999; Van Laere et al., 2008] (fig. 1). Loci located within the PAR behave similar to autosomal loci: they are diploid, undergo recombination in males and females and are not subject to dosage compensation by $\mathrm{X}$ inactivation in females [Ellis and Goodfellow, 1989; Brown and Greally, 2003; Bondy and 
Cheng, 2009; Prothero et al., 2009; Urbach and Benvenisty, 2009]. These features led to naming of the region as 'pseudoautosomal' [Burgoyne, 1982], primarily to indicate the autosome-like properties, despite being on the sex chromosomes.

While the physical boundary of the PAR is demarcated by the $\mathrm{PAB}$, functionally the region is defined by recombination. Because the PAR is a small region and because there is one obligatory cross-over in male meiosis, the overall recombination frequency in the PAR is high, exceeding the genome average 10-20 times [Filatov, 2004; Flaquer et al., 2009].

These almost canonical facts are exclusively based on the studies of human [Skaletsky et al., 2003; Ross et al., 2005] and mouse [Ellison et al., 1996; Palmer et al., 1997; Gianfrancesco et al., 2001; Perry et al., 2001] PARs, while only limited information is available for other mammals, including the domestic species. Ironically, though the mammalian PAR was first discovered in rats [Koller and Darlington, 1934], the size and gene content of the region in rats is still not determined.

\section{The Human and Mouse PARs}

The human (Homo sapiens, HSA) PAR is undoubtedly the best characterized due to the availability of annotated sequence data for both the $\mathrm{X}$ [Ross et al., 2005] and the $\mathrm{Y}$ chromosome [Skaletsky et al., 2003]. Notably, human is thus far the only eutherian species known to have 2 PARs. The PAR1 [Ellis and Goodfellow, 1989; Ellis et al., 1989], at the tip of HSAXp/Yp, shares similarity with other eutherian PARs, while PAR2 at HSAXq/Yq is strictly human-specific and is not found even in chimpanzee [Ciccodicola et al., 2000; Charchar et al., 2003; Hughes et al., 2010]. Since the PAR 2 has no homology in other mammals and because only 2 of the 4 PAR 2 genes escape $\mathrm{X}$ inactivation [De Bonis et al., 2006], the region has little relevance to genetic changes associated with sex chromosome aneuploidies and is not included in further discussion.

The physical boundary of the PAR1 is demarcated by the $X G$ blood group gene at $2.67 \mathrm{Mb}$ [Pritchard et al., 1987; Goodfellow et al., 1988; Ellis et al., 1989; Galtier, 2004; Ross et al., 2005; Blaschke and Rappold, 2006]. The PAR1 contains 24 genes and shows relatively higher gene density $(10$ genes $/ \mathrm{Mb})$ than the rest of HSAX $(7$ genes $/ \mathrm{Mb})$ [Ross et al., 2005] or HSAY (3 genes/Mb) [Skaletsky et al., 2003]. However, given that $20 \%$ of PAR 1 sequence is not yet available [Ross et al., 2005], the proposed size and gene density for the human PAR1 are rough estimates.
Interestingly, the PARs in other primates differ from human PAR1 in size and gene content. For example, the Alu repeat is present at the PAB of human and great apes, but not in the Old World monkeys [Ellis et al., 1990]. In lemurs, the PAR has moved to the tip of the Xq and incorporates genes that are X-specific in human [Gläser et al., 1997, 1999].

The mouse (Mus musculus, MMU) PAR is the second most studied after human and, remarkably, shares no homology with the human PAR1 or any other eutherian PARs. The region is approximately one-quarter the size $(\sim 700 \mathrm{~kb})$ of the human PAR 1 and contains only 3 known protein coding genes [Ellison et al., 1996; Gianfrancesco et al., 2001; Peterlin et al., 2004]. Similar to humans, the mouse PAB is spanned by a gene, Mid1, which is truncated on MMUY [Palmer et al., 1997; Perry et al., 2001]. As far as known, the murine PAR is the smallest and the gene poorest among eutherians.

\section{The PAR in Domestic Species}

The remarkable differences between the human and mouse PARs and the observed variation between the PARs in primates pose outstanding questions: is the variation in PAR size and gene content a common feature among mammals; what is the extent of the variation, and what could be the genetic consequences of these differences? Some answers come from the recent PAR studies in domestic species.

The PAR has been mapped to the ends of both sex chromosomes in almost all domestic species, viz., dog [Olivier et al., 1999; Young et al., 2008], horse [Shiue et al., 2000; Raudsepp and Chowdhary, 2008], bovidscaprids [Iannuzzi et al., 2000a; Di Meo et al., 2005; Das et al., 2009], pig [Quilter et al., 2002], cat [Murphy et al., 2007; Pearks Wilkerson et al., 2008], and alpaca [own unpublished data]. On the $\mathrm{X}$ chromosome, which is evolutionarily conserved among mammals [Ohno, 1967; Raudsepp et al., 2004a], the PAR is typically located at Xpter (fig. 2), as is PAR1 in humans. The only known exceptions are bovids where, due to $\mathrm{X}$ chromosome rearrangements, the PAR has moved to the end of the long arm $(\mathrm{Xq})$. The location of the PAR on the Y chromosome, which is not evolutionarily conserved [Raudsepp et al., 2004b], varies more and differs even between closely related species, e.g. the ruminants (fig. 2). The location of the PAR on the long or short arm of the sex chromosomes does not affect X-Y pairing, but might have genetic implications in case of structural chromosomal re- 


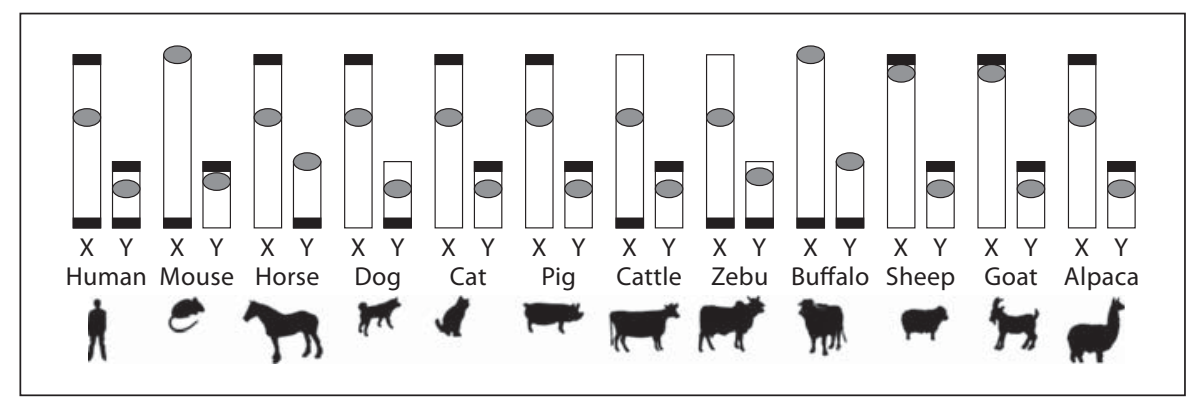

Fig. 2. A schematic showing the location of the PAR on the sex chromosomes of human, mouse and 10 domestic species. Black rectangles mark the PAR; grey ovals show the position of the centromeres. The information is retrieved from the following sources: human [Skaletsky et al., 2003; Ross et al., 2005], mouse [Perry et al., 2001], horse [Raudsepp and Chowdhary, 2008], dog [Olivier et al., 1999; Lindblad-Toh et al., 2005], cat [Murphy et al., 2007; Pearks Wilkerson et al., 2008], pig [Quilter et al., 2002], cattle, zebu, river buffalo, goat, and sheep [Iannuzzi et al., 2000a; Di Meo et al., 2005; Das et al., 2009], and alpaca [own unpublished observations]. arrangements. For example, isochromosome formation might result in complete deletion or duplication of the region on one of the sex chromosomes [see Das et al., 2011, this issue].

\section{Dog and Cat}

Despite the evolutionary conservation of the mammalian X chromosome, the location of the PAR alone, without demarcation of the $\mathrm{PAB}$, provides no information about the actual size and gene content of the region. For example, sequence draft assembly of the dog X chromosome has been available since 2005 [Lindblad-Toh et al., 2005]. However, the canine PAB and, thus, the physical domain of the PAR was determined only recently [Young et al., 2008]. Notably, the canine PAR is $\sim 6.6 \mathrm{Mb}$ in size, thus more than two times larger than human PAR1. It extends proximal to SHROOM2 and contains at least 34 protein coding genes (Ensembl: http://www.ensembl.org/ index.html) [Young et al., 2008]. Though sequence assembly for the cat X chromosome is not complete (Ensembl website; UCSC: http://genome.ucsc.edu/cgi-bin/ hgGateway), radiation hybrid mapping suggests that the cat PAB is also located between SHROOM2 and WWC3 genes [Murphy et al., 2007]. The PARs of the 2 species are, thus, very similar in gene content but might differ in size because in dog X chromosome, SHROOM2 is located at $6.4 \mathrm{Mb}$ and in cat at $8.0 \mathrm{Mb}$ (UCSC website).

Dog is so far the only domestic species with a complete sequence map available for the PAR. In other species where whole genome draft assembly is available, like horse [Wade et al., 2009] and cattle [Bovine Genome Sequencing and Analysis Consortium et al., 2009], the PAR sequence is incomplete (horse) or largely missing (cattle).
Therefore, the PARs of other domestic species have been characterized through various mapping efforts.

\section{Horse}

A high-resolution BAC contig map is available for the horse PAR and shows that the region is about $1.8 \mathrm{Mb}$ in size, thus the smallest among domestic species, and contains 18 genes [Raudsepp and Chowdhary, 2008]. Interestingly, while the equine PAR and the human PAR1 are largely collinear on the $\mathrm{X}$ chromosome, the $\sim 0.9 \mathrm{Mb}$ smaller horse PAR contains 12 genes that are X-specific in humans. The horse PAB is located between PRKXY and NLGN4X in the X chromosome, and between PRKXY and EIF1AY in the Y chromosome.

\section{Cattle, Goat, Sheep, and Other Ruminants}

The physical domain of cattle/ruminant PAR is demarcated by the GPR143 gene which spans the PAB in cattle, zebu, bison, yak, banteng, and sheep [Van Laere et al., 2008]. Thus, SHROOM2, which is a PAR gene in cat and dog, is X-specific in cattle/ruminants. Furthermore, PLCXD1, the most terminal PAR gene in dog, human and horse, is located in the X-specific region in cattle [Das et al., 2009]. Despite containing fewer genes than the PARs in cat and dog, the physical size of the cattle/ruminant PAR might be larger, over $9 \mathrm{Mb}$, as estimated from homologous region in HSAXp [Das et al., 2009]. The observed discrepancy between the PAR size and gene content, as seen between dog/cat and cattle, and between human and horse, can be attributed to variations in the content of repetitive sequences in different species. As a result, sequences which are collinear in gene content are not necessarily equal in size. 


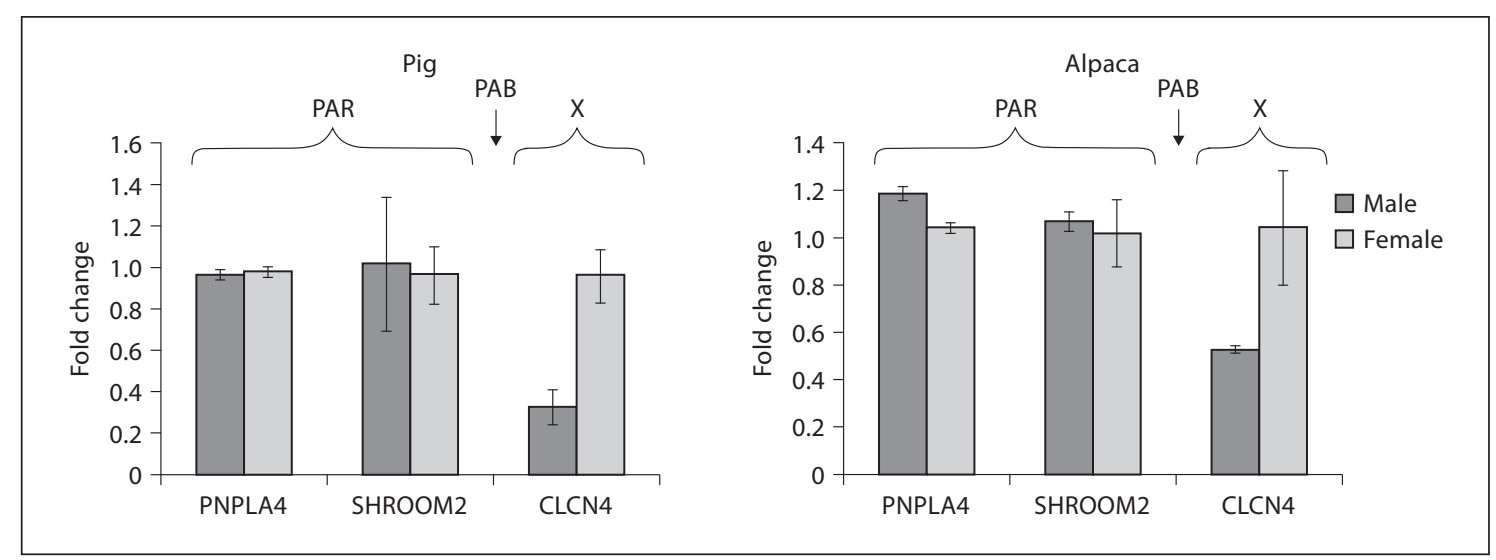

Fig. 3. The approximate location of the PAB in pig and alpaca X chromosomes. Genomic copy numbers were determined by quantitative real-time PCR (qRT-PCR): PNPLA4 and SHROOM2 with male/female copy number ratio 1:1 are located in the PAR; CLCN4 with male/female copy number ratio 1:2 is located in the X-specific region.

\section{Pig and Alpaca}

Even though the pig genome is well studied, mapped and sequenced [see Raudsepp and Chowdhary, 2011], and the alpaca genome is not, the 2 species are quite equal regarding the knowledge about their PARs. Neither has a well-developed map or sequence information for the region. However, very recently, using quantitative real-time polymerase chain reaction, the putative $\mathrm{PAB}$ was demarcated in both species [own unpublished data]. Comparing the female-to-male copy number ratios which should be 1 for PAR genes and 2 for X-specific genes, the pig and alpaca $\mathrm{PAB}$ was mapped between SHROOM2 and CLCN4 (fig. 3) on the X chromosome. Thus, the 2 PARs might be more similar to those of carnivores than ruminants.

Taken together, the physical domain of the PAR has been determined in 6 domestic species (ruminants are considered as one), and notably, all 6 PARs differ from each other as well as from human and mouse PARs (fig. 4). This provides 2 important messages. First, while mouse PAR is an outlier among eutherians, the human PAR1 as well does not represent an average mammalian PAR. Thus, the salient properties of the PAR as revealed from human and mouse studies might not apply to all species. Secondly and most importantly, since the PARs differ in size and gene content, the number of functional genes that escape $\mathrm{X}$ inactivation and are the only truly diploid genes on both sex chromosomes, is also different between species. If so, does the size and gene content of the PAR influence the genetic effect of sex chromosome aneuploidies?

\section{Sex Chromosome Aneuploidies}

A variety of sex chromosome aneuploidies have been described in domestic species [Chowdhary, 1998; Chowdhary and Raudsepp, 2000; Ducos et al., 2007, 2008; King, 2008; Lear and Bailey, 2008; Villagomez and Pinton, 2008; Villagomez et al., 2009; Durkin et al., 2011; Raudsepp and Chowdhary, 2011]. The majority of those are in mosaic form, where chromosomally normal cells contribute to the phenotype together with cells containing an abnormal number of sex chromosomes, thus blurring the dosage effect of the genes that escape $\mathrm{X}$ inactivation. Among non-mosaic aneuploidies, there are those which cause haploinsufficiency for the PAR, such as Xmonosomy, and those that increase the PAR dosage, such as XXX, XXY and XYY genotypes. However, in aneuploidies involving the $\mathrm{Y}$ chromosome, the phenotypic effects of PAR overdose might be masked by testis determining function of the $S R Y$ gene [Sinclair et al., 1990]. Therefore, in the following discussion, only non-mosaic cases of Xmonosomy and X-trisomy in different species will be considered.

\section{X-Monosomy}

$\mathrm{X}$-monosomy is a relatively common sex chromosome abnormality in humans, affecting approximately 1 in 2,500 live female births (0.04\%) [Lynn and Davies, 2007; Bondy and Cheng, 2009]. The condition is over 200 times more frequent among conceptuses but seriously affects embryonic viability causing spontaneous abortions. Meta-analysis of over 10,000 human miscarriages shows that 


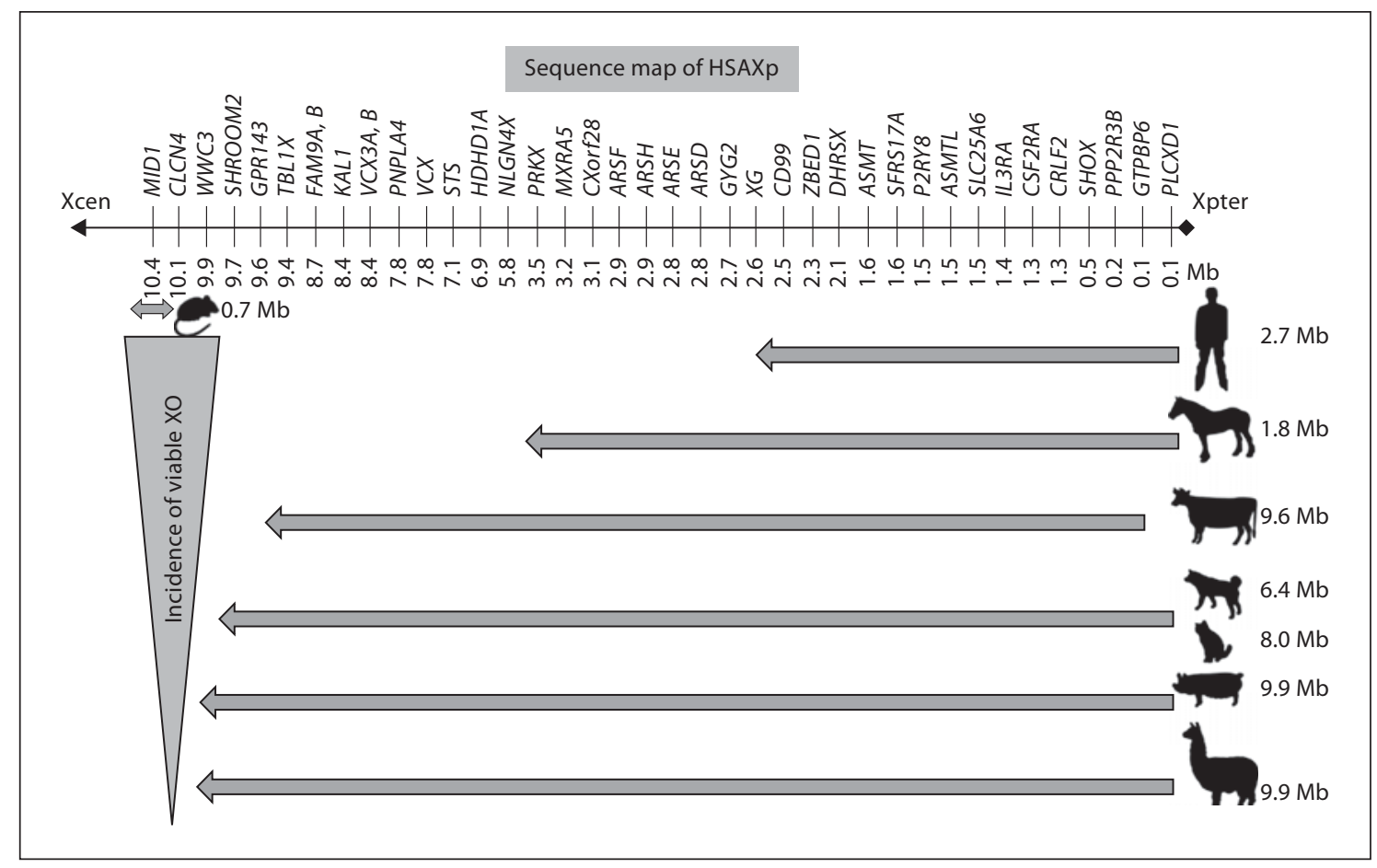

Fig. 4. Correlation between the incidence of viable X chromosome monosomy (left) and the size and gene content of the PAR in human, mouse and domestic species. Sequence map of HSAXp is shown at the top and serves as a reference for the PAR size and gene content for all other species. Bold grey arrows with species shapes at the right demarcate the span of their PARs; $\mathrm{Mb}$ at the right to each species depict the approximate size of their PAR; cattle/ruminant PAR starts at GTPBP6 locus because PLCXD1 is X-specific in these species.

about $10 \%$ have 45,XO karyotype [Menasha et al., 2005]. The few embryos that survive are depleted of oocytes and give rise to sterile females. Also, the XO human females have short stature and might suffer from cardiovascular and neuropsychiatric disorders [Lynn and Davies, 2007; Bondy and Cheng, 2009].

In contrast, X-monosomic mice grow and develop normally, are fertile and have no major congenital defects [Probst et al., 2008] except that the XO mice have less oocytes compared to normal XX mice and become prematurely sterile [Burgoyne and Baker, 1981]. Interestingly, $\mathrm{XO}$ mice also exhibit a distinct neurocognitive phenotype and are proposed as a model for the neurobiology of human XO syndrome [Lynn and Davies, 2007].

Apart from human and mouse, the only other species where $\mathrm{XO}$ syndrome has been reported frequently is the horse. Since 1968, when the first equine case of X-monosomy was detected [Payne et al., 1968], there have been at least 30 publications describing over $150 \mathrm{XO}$ mares (table 1) [reviewed by Power, 1990; Chowdhary and Raudsepp, 2000; Lear and Bailey, 2008; Villagomez et al.,
2009]. The XO syndrome is indisputably the most frequent chromosomal defect in horses accounting for approximately $36 \%$ of all sex chromosome abnormalities [Power, 1990; Chowdhary and Raudsepp, 2000; Lear and Bailey, 2008; Villagomez et al., 2009]. In a genotypingbased survey in a large population of newborn foals ( $\mathrm{n}=$ 17,471), 63 ,XO karyotype was detected in $0.15 \%$ of female animals [Kakoi et al., 2005] suggesting that the incidence of viable X-monosomy in horse populations might be quite similar to those in humans. Likewise, all XO mares studied up till now were sterile. Other characteristic features of the equine condition, such as shorter than normal stature, small gonads lacking follicular development, and irregular or absent estrus cycle [Power, 1990; Chowdhary and Raudsepp, 2000] are also similar to the Turner syndrome in humans [Bondy and Cheng, 2009]. However, no information is available about the frequency of spontaneously aborted equine $\mathrm{XO}$ embryos.

In contrast to human and horse, reports about viable $\mathrm{XO}$ individuals among other domestic species are rare, less than 10 cases per species since the 1970s [Villagomez 
et al., 2009] (table 1). Regardless of the species, all XO females studied so far are sterile. Because there are wellestablished cytogenetic survey systems for the main agricultural species in many countries worldwide [Ducos et al., 2008], and because the causes of meiotic nondisjunctions are not species-dependent, the low incidence of XO females in cattle/ruminants, pigs, dogs, cats, and alpacas might be due to genetic reasons. Indeed, not coincidentally, all species with low numbers of XO individuals have large, over $6 \mathrm{Mb}$ in size, PARs (fig. 3). This implies that the loss of one $\mathrm{X}$ chromosome causes haploinsufficiency for a larger genomic segment and involves more genes than, for example, in mouse, human or horse. Though there are no statistics and cytogenetic surveys about spontaneous abortions in domestic animals, we theorize that such genetic losses are not compatible with viability. Therefore, it is anticipated that in species with larger PARs, the incidence of spontaneously aborted XO embryos is higher than the $10 \%$ reported for human miscarriages [Menasha et al., 2005].

\section{X-Trisomy}

While there seems to be a direct link between embryonic viability and the reduced dosage of PAR genes, only minor phenotypic effects are associated with the PAR overdose. Systematic studies of X chromosome trisomy in humans [Tartaglia et al., 2010] demonstrate that 47,XXX karyotype is the most common female chromosome abnormality affecting $1 / 1,000$ female births. Survival of human fetuses with X-trisomy is about $99 \%$. The phenotype varies considerably, ranging from almost normal fertile females to those having seizures, renal and genitourinary abnormalities, and premature ovarian failure. Because of relatively mild phenotypic effect, only $10 \%$ of the cases are ascertained clinically. Typical to almost all XXX individuals is tall stature, contrasting the short stature phenotype associated with the XO syndrome [Bondy and Cheng, 2009; Tartaglia et al., 2010].

In domestic animals, pure trisomy of the $\mathrm{X}$ chromosome is not frequent (table 1). In horses, only 11 cases have been reported, and the majority of 65, XXX mares are phenotypically normal but infertile [Chowdhary and Raudsepp, 2000]. Since infertility is usually the primary reason why horses are subjected to karyotyping, it is possible that more $65, \mathrm{XXX}$ mares might be present in the general population, but due to normal fertile phenotype (like XXX humans) have escaped detection [Power, 1990]. Non-mosaic X-chromosome trisomy has also been found in cattle, river buffalo, dog, and alpaca (table 1). In cattle and river buffalo, some animals are fertile [Yadav and
Balakrishnan, 1982] or subfertile [Swartz and Vogt, 1983], while others have impaired reproductive physiology and are sterile [Prakash et al., 1994; Moreno-Millan et al., 1987]. The single $X$-trisomy case found in dogs was associated with gonadal dysgenesis [Johnston et al., 1985]. Because of so few reported cases, no clear correlation between the occurrence of X-trisomy and the size of the PAR in different species could be pointed out. Nevertheless, in the horse, the species with the smallest PAR among animals, almost twice as many XXX reports have been published compared to other domestic species (table 1).

These data for XO and XXX conditions in domestic animals are in line with the cytogenetic analyses carried out between 2001-2011 at the Molecular Cytogenetic Laboratory, Texas A\&M University [own unpublished data]. Among 216 female horses with various reproductive problems, 32 mares (15\%) had 63,XO and one a 65 ,XXX karyotype. In contrast, chromosome analysis of over 30 cattle, sheep and goats, 36 pigs, 75 dogs, and 74 alpacas/llamas collectively identified just one 59 , XO heifer. The animal was born as a result of embryo transfer and had cytogenetically normal siblings.

Taken together, the available information shows that viable $\mathrm{XO}$ individuals are relatively frequently found in species with small PARs, such as horses [Raudsepp and Chowdhary, 2008], humans [Ross et al., 2005] and mice [Perry et al., 2001], but are rare or absent in species where the PAR is substantially larger, as in cattle/ruminants [Van Laere et al., 2008; Das et al., 2009], dogs [Young et al., 2008], pigs, and alpacas [own unpublished data]. No similar correlation can be pointed out between the PAR size and the X chromosome trisomy in different species. This is probably because of a milder genetic effect of the PAR overdose compared to haploinsufficiency, due to which many XXX cases might remain undetected.

Why is embryonic viability more affected by the reduced dosage than the overdose of the PAR? What are the functions of the PAR genes? Are PAR genes critically involved in embryonic development? These are just some of the questions that arise from the above summarized observations. Yet, there are very few answers.

\section{The Functions of the PAR Genes}

Despite of extensive search for the molecular basis of sex chromosome aneuploidies, such as XO, XXX and $\mathrm{XXY}$ syndromes in humans [Tuttelmann and Gromoll, 2010; Urbach and Benvenisty, 2009] and mice [Lopes et al., 2010], surprisingly little is known about the expres- 
Table 1. Summary of the published data about the occurrence of non-mosaic X chromosome monosomy and trisomy in domestic species

\begin{tabular}{|c|c|c|c|c|}
\hline Species & $\mathrm{XO}$ references & $\begin{array}{l}\text { No of XO } \\
\text { cases }\end{array}$ & $\mathrm{XXX}$ references & $\begin{array}{l}\text { No of XXX } \\
\text { cases }\end{array}$ \\
\hline Horse & $\begin{array}{l}\text { Payne et al., } 1968 \\
\text { Chandley et al., 1975 } \\
\text { Hughes et al., 1975; Hughes and Kennedy, } 1975 \\
\text { Taylor and Trommershausen-Smith, } 1975 \\
\text { Hughes and Trommershausen-Smith, } 1977 \\
\text { Blue et al., } 1978 \\
\text { Bruère et al., } 1978 \\
\text { Metenier et al., } 1979 \\
\text { Miyake et al., } 1979 \\
\text { Trommershausen-Smith et al., } 1979 \\
\text { Hughes et al., } 1980 \\
\text { Cribiu and Losfeld, } 1982 \\
\text { Buoen et al., } 1983 \\
\text { Halnan, } 1985 \\
\text { Makinen et al., } 1986 \\
\text { Bowling et al., } 1987 \\
\text { Long, } 1988 \\
\text { Buoen et al., } 1993 \\
\text { Breen et al., } 1997 \\
\text { Makinen et al., } 2001 \\
\text { Bugno et al., } 2003 b \\
\text { Kakoi et al., } 2005 \\
\text { Bugno et al., } 2009 \\
\text { Di Meo et al., } 2009\end{array}$ & $\begin{array}{r}1 \\
2 \\
4 \\
5 \\
5 \\
1 \\
6 \\
1 \\
3 \\
12 \\
21 \\
1 \\
1 \\
1 \\
1 \\
56 \\
1 \\
1 \\
2 \\
1 \\
1 \\
13 \\
1 \\
1\end{array}$ & $\begin{array}{l}\text { Chandley et al., } 1975 \\
\text { Bowling et al., } 1987 \\
\text { Stewart-Scott, } 1988 \\
\text { Moreno-Millan et al., } 1989 \\
\text { Power and Leadon, } 1990 \\
\text { Nie et al., 1993 } \\
\text { Bugno et al., 2003a } \\
\text { Kakoi et al., 2005 } \\
\text { de Lorenzi et al., } 2010\end{array}$ & $\begin{array}{l}1 \\
5 \\
1 \\
1 \\
1 \\
1 \\
1 \\
1 \\
1\end{array}$ \\
\hline Cattle & Prakash et al., 1995 & 1 & $\begin{array}{l}\text { Pinheiro et al., } 1987 \\
\text { Herzog et al., } 1977 \\
\text { Rieck et al., } 1970 \\
\text { Norberg et al., } 1976 \\
\text { Buoen et al., } 1981 \\
\text { Moreno-Millan et al., } 1987\end{array}$ & $\begin{array}{l}1 \\
1 \\
1 \\
1 \\
1 \\
1\end{array}$ \\
\hline Sheep/Goat & Zartman et al., 1981 & 1 & No reports & 0 \\
\hline River Buffalo & $\begin{array}{l}\text { Yadav et al., } 1990 \\
\text { Prakash et al., } 1992 \\
\text { Iannuzzi et al., } 2000 \mathrm{~b} \\
\text { Di Meo et al., } 2008\end{array}$ & $\begin{array}{l}1 \\
1 \\
1 \\
2\end{array}$ & $\begin{array}{l}\text { Yadav and Balakrishnan, } 1982 \\
\text { Prakash et al., } 1994 \\
\text { Iannuzzi et al., } 2004 \\
\text { Di Meo et al., } 2008\end{array}$ & $\begin{array}{l}1 \\
1 \\
1 \\
1\end{array}$ \\
\hline Pig & $\begin{array}{l}\text { Nes, } 1968 \\
\text { Lojda, } 1975\end{array}$ & $\begin{array}{l}1 \\
1\end{array}$ & No reports & 0 \\
\hline Dog & $\begin{array}{l}\text { Lofstedt et al., } 1992 \\
\text { Mayr et al., } 1991 \\
\text { Giger et al., } 1989 \\
\text { Smith et al., } 1989\end{array}$ & $\begin{array}{l}1 \\
1 \\
1 \\
1\end{array}$ & $\begin{array}{l}\text { Goldschmidt et al., } 2006 \\
\text { Johnston et al., } 1985 \\
\text { Switonski et al., } 2000\end{array}$ & $\begin{array}{l}1 \\
1 \\
1\end{array}$ \\
\hline Cat & Johnston et al., 1983 & 1 & No reports & 0 \\
\hline Alpaca/ Llama & $\begin{array}{l}\text { Hinrichs et al., } 1997 \\
\text { Tibary et al., } 2008\end{array}$ & $\begin{array}{l}1 \\
1\end{array}$ & Tibary et al., 2008 & 1 \\
\hline
\end{tabular}


sion profiles, the possible functions and genotype-phenotype correlations of PAR genes. For a long time, the human SHOX was the only known PAR-linked disease locus responsible for the short stature in XO Turner syndrome [Blaschke and Rappold, 2006; Mangs and Morris, 2007; Bondy and Cheng, 2009] and the tall stature typical for XXX [Tartaglia et al., 2010] and XXY Kleinfelter [Tuttelmann and Gromoll, 2010] syndromes. In addition, a susceptibility locus for bipolar affective disorder was recently discovered in human PAR1 [Flaquer et al., 2010]. These findings, however, do not explain the high rate of lethality of human XO embryos and differential survival of XO individuals in different species.

A breakthrough regarding the possible functions of PAR genes came recently from human stem cell studies showing that the only tissue where genes from human XX and XO embryonic stem cells are differentially expressed is placenta [Urbach and Benvenisty, 2009]. The authors suggest that genes in the PAR, as well as other genes that escape $\mathrm{X}$ inactivation, might have an important role in placental development. This explains the high rate of lethality (70-99\%) of XO embryos in humans [Bondy and Cheng, 2009; Urbach and Benvenisty, 2009; Berletch et al., 2010]. If certain expression levels of PAR genes are critical in early development, changes in the dosage of these genes, especially haploinsufficiency, will seriously affect the survival of the developing embryo. Consequently, the size and gene content of the PAR might be decisive in determining the viability of embryos carrying sex chromosome aneuploidies in different species. Furthermore, recently discovered association of recombination hot spots with DNA methylation and imprinting [Luedi et al., 2007; Sigurdsson et al., 2009] suggest that PAR genes might be subject to genomic imprinting. Elevated expression of PAR genes in placenta [Urbach and Benvenisty, 2009] might be an evidence for this. Indeed, maternally and paternally imprinted loci were recently discovered in the PAR of pigs [Duthie et al., 2009], supporting the role of PAR genes in early development.

And this is not all. In humans, about $15 \%$, and in mouse, about $3 \%$ of X-linked non-PAR genes escape $\mathrm{X}$ inactivation [Berletch et al., 2010], thus contributing to the dosage of functional genes in $\mathrm{X}$ chromosome aneuploidies. Though the escape genes have not yet been characterized in any of the domestic species, their role in the genetic consequences of sex chromosome aneuploidies cannot be ignored and should be a subject for immediate future studies.

\section{Summary}

The current body of knowledge regarding the PAR in domestic species, though limited, provides evidence that differences in the size and gene content of the region might critically implicate embryonic survival and postnatal phenotypes of the carriers of sex chromosome aneuploidies. Genetic causes of these effects are not fully understood, but there are indications that the PAR and other escape genes might be critically involved in placenta formation and genomic imprinting during early development. This implies that the functional significance of the PAR is not limited to sex chromosome segregation in male meiosis, encouraging the launch of systematic expression studies of PAR genes at different stages of development in domestic species.

\section{Acknowledgements}

This work was supported by USDA (2006-04801), CVMBS LINK Endowment for Equine Genomics, Morris Animal Foundation (D09LA-004) and Alpaca Research Foundation.

\section{References}

Berletch JB, Yang F, Disteche CM: Escape from $\mathrm{X}$ inactivation in mice and humans. Genome Biol 11:213 (2010).

Blaschke RJ, Rappold G: The pseudoautosomal regions, SHOX and disease. Curr Opin Genet Dev 16:233-239 (2006).

Blue MG, Bruère AN, Dewes HF: The significance of the XO syndrome in infertility of the mare. N Z Vet J 26:137-141 (1978).

Bondy CA, Cheng C: Monosomy for the X chromosome. Chromosome Res 17:649-658 (2009).
Bovine Genome Sequencing and Analysis Consortium, Elsik CG, Tellam RL, Worley KC, Gibbs RA, et al: The genome sequence of taurine cattle: a window to ruminant biology and evolution. Science 324:522-528 (2009).

Bowling AT, Millon L, Hughes JP: An update of chromosomal abnormalities in mares. J Reprod Fertil Suppl 35:149-155 (1987).

Breen M, Langford CF, Carter NP, Fischer PE, Marti E, et al: Detection of equine X chromosome abnormalities in equids using a horse $\mathrm{X}$ whole chromosome paint probe (WCPP). Vet J 153:235-238 (1997).
Breen M, Hitte C, Lorentzen TD, Thomas R, Cadieu E, et al: An integrated 4249 marker FISH/RH map of the canine genome. BMC Genomics 5:65 (2004).

Brown CJ, Greally JM: A stain upon the silence: genes escaping $\mathrm{X}$ inactivation. Trends Genet 19:432-438 (2003).

-Bruère AN, Blue MG, Jaine PM, Walker KS, Henderson LM, Chapman HM: Preliminary observations on the occurrence of the equine XO syndrome. N Z Vet J 26:145-146 (1978). 
-Bugno M, Klukowska J, Slota E, Tischner M, Switonski M: A sporadic case of the sex-reversed mare (64,XY; SRY-negative): molecular and cytogenetic studies of the Y chromosome. Theriogenology 59:1597-1603 (2003a).

Bugno M, Slota E, Wieczorek M, Yang F, Buczynski J, Switonski M: Nonmosaic X trisomy, detected by chromosome painting, in an infertile mare. Equine Vet J 35:209-210 (2003b).

-Bugno M, Slota E, Pienkowska-Schelling A, Schelling C: Identification of chromosome abnormalities in the horse using a panel of chromosome-specific painting probes generated by microdissection. Acta Vet Hung 57: 369-381 (2009).

Buoen LC, Seguin BE, Weber AF, Shoffner RN: $\mathrm{X}$-trisomy karyotype and associated infertility in a Holstein heifer. J Am Vet Med Assoc 179:808-811 (1981).

Buoen LC, Eilts BE, Rushmer A, Weber AF: Sterility associated with an $\mathrm{XO}$ karyotype in a Belgian mare. J Am Vet Med Assoc 182: 1120-1121 (1983).

Buoen LC, Zhang TQ, Ruth GR, Weber AF, Kittleson SL: Sterility associated with an XO karyotype in a miniature horse mare. Equine Vet J 25:164-165 (1993).

Burgoyne PS: Genetic homology and crossing over in the X and Y chromosomes of Mammals. Hum Genet 61:85-90 (1982).

Burgoyne PS, Baker TG: Oocyte depletion in XO mice and their XX sibs from 12 to 200 days post partum. J Reprod Fertil 61:207-212 (1981).

Chandley AC, Fletcher J, Rossdale PD, Peace CK, Ricketts SW, et al: Chromosome abnormalities as a cause of infertility in mares. J Reprod Fertil Suppl:377-383 (1975)

-Chantry-Darmon C, Urien C, de Rochambeau $\mathrm{H}$, Allain D, Pena B, et al: A first-generation microsatellite-based integrated genetic and cytogenetic map for the European rabbit (Oryctolagus cuniculus) and localization of angora and albino. Anim Genet 37:335-341 (2006).

-Charchar FJ, Svartman M, El-Mogharbel N, Ventura M, Kirby P, et al: Complex events in the evolution of the human pseudoautosomal region 2 (PAR2). Genome Res 13:281286 (2003).

Charlesworth D, Charlesworth B, Marais G: Steps in the evolution of heteromorphic sex chromosomes. Heredity 95:118-128 (2005).

Chowdhary BP: Cytogenetics and physical chromosome maps, in Rothschild MF, Ruvinsky A (eds): The Genetics of the Pig, pp. 199-264 (CABI International, Wallingford 1998).

Chowdhary BP, Raudsepp T: Cytogenetics and physical gene maps, in Bowling AT, Ruvinsky A (eds): The Genetics of the Horse, pp. 171-242 (CABI International, Wallingford 2000).

Ciccodicola A, D’Esposito M, Esposito T, Gianfrancesco F, Migliaccio C, et al: Differentially regulated and evolved genes in the fully sequenced $\mathrm{Xq} / \mathrm{Yq}$ pseudoautosomal region. Hum Mol Genet 9:395-401 (2000).
Cribiu EP, Losfeld P: Two further cases of XO and $\mathrm{XO} / \mathrm{XX}$ chromosome constitution in mares. 5th European Colloquium on Cytogenetics of Domestic Animals, Milan, June 1982.

Das PJ, Chowdhary BP, Raudsepp T: Characterization of the bovine pseudoautosomal region and comparison with sheep, goat, and other mammalian pseudoautosomal regions. Cytogenet Genome Res 126:139-147 (2009).

Davis BW, Raudsepp T, Pearks Wilkerson AJ, Agarwala R, Schaffer AA, et al: A high-resolution cat radiation hybrid and integrated FISH mapping resource for phylogenomic studies across Felidae. Genomics 93:299-304 (2009).

De Bonis ML, Cerase A, Matarazzo MR, Ferraro M, Strazzullo M, et al: Maintenance of Xand Y-inactivation of the pseudoautosomal (PAR2) gene SPRY3 is independent from DNA methylation and associated to multiple layers of epigenetic modifications. Hum Mol Genet 15:1123-1132 (2006).

de Lorenzi L, Molteni L, Zannotti M, Galli C, Parma P: X trisomy in a sterile mare. Equine Vet J 42:469-470 (2010).

Di Meo GP, Perucatti A, Floriot S, Incarnato D, Rullo R, et al: Chromosome evolution and improved cytogenetic maps of the $\mathrm{Y}$ chromosome in cattle, zebu, river buffalo, sheep and goat. Chromosome Res 13:349-355 (2005).

-Di Meo GP, Perucatti A, Di Palo R, Iannuzzi A, Ciotola F, et al: Sex chromosome abnormalities and sterility in river buffalo. Cytogenet Genome Res 120:127-131 (2008).

-Di Meo GP, Neglia G, Perucatti A, Genualdo V, Iannuzzi A, et al: Numerical sex chromosome aberrations and abnormal sex development in horse and sheep. Sex Dev 3:329-332 (2009).

Ducos A, Berland HM, Bonnet N, Calgaro A, Billou, S, et al: Chromosomal control of pig populations in France: 2002-2006 survey. Genet Sel Evol 39:583-597 (2007).

Ducos A, Revay T, Kovacs A, Hidas A, Pinton A, et al: Cytogenetic screening of livestock populations in Europe: an overview. Cytogenet Genome Res 120:26-41 (2008).

Durkin K, Raudsepp T, Chowdhary BP: Cytogenetic evaluation of the stallion, in McKinnon AO, Squires EL, Vaala WE, Varner DD (eds): Equine Reproduction, pp 1462-1468 (Wiley Blackwell, 2011).

Duthie CA, Simm G, Pérez-Enciso M, DoeschlWilson A, Kalm E, et al: Genomic scan for quantitative trait loci of chemical and physical body composition and deposition on pig chromosome $\mathrm{X}$ including the pseudoautosomal region of males. Genet Sel Evol 41:27 (2009).

Ellis N, Goodfellow PN: The mammalian pseudoautosomal region. Trends Genet 5:406 410 (1989).
Ellis N, Yen P, Neiswanger K, Shapiro LJ, Goodfellow PN: Evolution of the pseudoautosomal boundary in Old World monkeys and great apes. Cell 63:977-986 (1990)

-Ellis NA, Goodfellow PJ, Pym B, Smith M, Palmer $\mathrm{M}$, et al: The pseudoautosomal boundary in man is defined by an Alu repeat sequence inserted on the Y chromosome. Nature 337: 81-84 (1989).

Ellison JW, Li X, Francke U, Shapiro LJ: Rapid evolution of human pseudoautosomal genes and their mouse homologs. Mamm Genome 7:25-30 (1996)

-Everts-van der Wind A, Kata SR, Band MR, Rebeiz M, Larkin DM, et al: A 1463 gene cattlehuman comparative map with anchor points defined by human genome sequence coordinates. Genome Res 14:1424-1437 (2004).

Filatov DA: A gradient of silent substitution rate in the human pseudoautosomal region. Mol Biol Evol 21:410-417 (2004).

-Flaquer A, Rappold GA, Wienker TF, Fischer C: The human pseudoautosomal regions: a review for genetic epidemiologists. Eur J Hum Genet 16:771-779 (2008).

Flaquer A, Fischer C, Wienker TF: A new sexspecific genetic map of the human pseudoautosomal regions (PAR1 and PAR2). Hum Hered 68:192-200 (2009).

Flaquer A, Jamra RA, Etterer K, Díaz GO, Rivas F, et al: A new susceptibility locus for bipolar affective disorder in PAR1 on Xp22.3/Yp11.3. Am J Med Genet B Neuropsychiatr Genet 153B:1110-1114 (2010).

Galtier N: Recombination, GC-content and the human pseudoautosomal boundary paradox. Trends Genet 20:347-349 (2004).

Gianfrancesco F, Sanges R, Esposito T, Tempesta $\mathrm{S}$, Rao E, et al: Differential divergence of three human pseudoautosomal genes and their mouse homologs: implications for sex chromosome evolution. Genome Res 11: 2095-2100 (2001).

- Giger U, Meyers-Wallen VN, Patterson DF: A 6-month-old Doberman pinscher with ambiguous genitalia as a first case of X-chromosomal monosomy in the dog. J Vet Intern Med 3:245 (1989).

Gläser B, Grützner F, Taylor K, Schiebel K, Meroni $G$, et al: Comparative mapping of Xp22 genes in hominoids-evolutionary linear instability of their Y homologues. Chromosome Res 5:167-176 (1997)

Gläser B, Myrtek D, Rumpler Y, Schiebel K, Hauwy M, et al: Transposition of SRY into the ancestral pseudoautosomal region creates a new pseudoautosomal boundary in a progenitor of simian primates. Hum Mol Genet 8:2071-2078 (1999).

Goldschmidt B, Paulino FO, Souza LM, Gomes HF: Infertility related to X-trisomy in a Labrador Retriever bitch. Israel J Vet Med 58 (2006).

Goodfellow PN, Pym B, Pritchard C, Ellis N, Palmer M, et al: MIC2: a human pseudoautosomal gene. Philos Trans R Soc Lond B Biol Sci 322:145-154 (1988). 
Halnan CR: Equine cytogenetics: role in equine veterinary practice. Equine Vet J 17:173-177 (1985).

Herzog A, Höhn H, Rieck GW: Survey of recent situation of chromosome pathology in different breeds of German cattle. Ann Genet Sel Anim 9:471-491 (1977).

-Hinrichs K, Horin SE, Buoen LC, Zhang TQ, Ruth GR: X-chromosome monosomy in an infertile female llama. J Am Vet Med Assoc 210:1503-1504 (1997)

-Hughes JF, Skaletsky H, Pyntikova T, Graves TA, van Daalen SK, et al: Chimpanzee and human Y chromosomes are remarkably divergent in structure and gene content. Nature 463:536-539 (2010).

-Hughes JP, Kennedy PC: XO-gonadal dysgenesis in the mare (report of two cases). Equine Vet J 7:109-112 (1975).

Hughes JP, Trommershausen-Smith A: Infertility in the horse associated with chromosomal abnormalities. Aust Vet J 53:253-257 (1977).

Hughes JP, Benirschke K, Kennedy PC, Trommershausen-Smith A: Gonadal dysgenesis in the mare. J Reprod Fertil Suppl 385-390 (1975).

-Hughes JP, Stabenfeldt GH, Kennedy PC: The estrous cycle and selected functional and pathologic ovarian abnormalities in the mare. Vet Clin North Am Large Anim Pract 2:225-239 (1980)

- Humphray SJ, Scott CE, Clark R, Marron B, Bender C, et al: A high utility integrated map of the pig genome. Genome Biol 8:R139 (2007).

- Iannuzzi L, Di Meo GP, Perucatti A, Incarnato D, Schibler L, Cribiu EP: Comparative FISH mapping of bovid $\mathrm{X}$ chromosomes reveals homologies and divergences between the subfamilies bovinae and caprinae. Cytogenet Cell Genet 89:171-176 (2000a).

-Iannuzzi L, Di Meo GP, Perucatti A, Zicarelli L: Sex chromosome monosomy $(2 \mathrm{n}=49, \mathrm{X})$ in a river buffalo (Bubalus bubalis). Vet Rec 147: 690-691 (2000b).

- Iannuzzi L, Di Meo GP, Perucatti A, Incarnato D, Di Palo R, Zicarelli L: Reproductive disturbances and sex chromosome abnormalities in two female river buffaloes. Vet Rec 154:823-824 (2004).

- Johnston SD, Buoen LC, Madl JE, Weber AF, Smith FO: X-Chromosome monosomy $(37, \mathrm{XO})$ in a Burmese cat with gonadal dysgenesis. J Am Vet Med Assoc 182:986-989 (1983).

-Johnston SD, Buoen LC, Weber AF, Madl JE: X trisomy in an Airedale bitch with ovarian dysplasia and primary anestrus. Theriogenology 24:597-607 (1985).

- Kakoi H, Hirota K, Gawahara H, Kurosawa M, Kuwajima M: Genetic diagnosis of sex chromosome aberrations in horses based on parentage test by microsatellite DNA and analysis of X-and Y-linked markers. Equine Vet J 37:143-147 (2005)
Kauppi L, Barchi M, Baudat F, Romanienko PJ, Keeney S, Jasin M: Distinct properties of the XY pseudoautosomal region crucial for male meiosis. Science 331:916-920 (2011).

King WA: Chromosome variation in the embryos of domestic animals. Cytogenet Genome Res 120:81-90 (2008).

Koller PC, Darlington CD: The genetical and mechanical properties of the sex chromosomes. I. Rattus norvegicus. J Genet 29:159173 (1934)

Lear TL, Bailey E: Equine clinical cytogenetics: the past and future. Cytogenet Genome Res 120:42-49 (2008).

Lindblad-Toh K, Wade CM, Mikkelsen TS, Karlsson EK, Jaffe DB, et al: Genome sequence, comparative analysis and haplotype structure of the domestic dog. Nature 438: 803-819 (2005).

Löfstedt RM, Buoen LC, Weber AF, Johnston SD, Huntington A, Concannon PW: Prolonged proestrus in a bitch with $\mathrm{X}$ chromosomal monosomy (77,XO). J Am Vet Med Assoc 200:1104-1106 (1992).

Lojda L: The cytogenetic pattern in pigs with hereditary intersexuality similar to the syndrome of testicular feminization in man. Doc Vet (Brno) 8:71-82 (1975).

Long SE: Chromosome anomalies and infertility in the mare. Equine Vet J 20:89-93 (1988).

Lopes AM, Burgoyne PS, Ojarikre A, Bauer J, Sargent CA, et al: Transcriptional changes in response to $\mathrm{X}$ chromosome dosage in the mouse: implications for $\mathrm{X}$ inactivation and the molecular basis of Turner Syndrome. BMC Genomics 11:82 (2010).

Luedi PP, Dietrich FS, Weidman JR, Bosko JM, Jirtle RL, Hartemink AJ: Computational and experimental identification of novel human imprinted genes. Genome Res 17:1723-1730 (2007).

Lynn PM, Davies W: The 39,XO mouse as a model for the neurobiology of Turner syndrome and sex-biased neuropsychiatric disorders. Behav Brain Res 179:173-182 (2007).

Makinen A, Katila T, Kuokkanen MT: XO syndrome in the mare. Nord Vet Med 38:16-21 (1986).

Mäkinen A, Suojala L, Niini T, Katila T, Tozaki $\mathrm{T}$, et al: X chromosome detection in an XO mare using a human $X$ paint probe, and PCR detection of $S R Y$ and amelogenin genes in 3 XY mares. Equine Vet J 33:527-530 (2001).

Mangs A, Morris BJ: The human pseudoautosomal region (PAR): origin, function and future. Curr Genomics 8:129-136 (2007).

Martin RH: Meiotic chromosome abnormalities in human spermatogenesis. Reprod Toxicol 22:142-147 (2006).

- Mayr B, Gilli H, Schleger W, Reifinger M, Burtscher H: Cytogenetic characterization of mammary tumors in two domestic dogs. Zentralbl Veterinarmed A 38:141-147 (1991).
Menasha J, Levy B, Hirschhorn K, Kardon NB: Incidence and spectrum of chromosome abnormalities in spontaneous abortions: new insights from a 12-year study. Genet Med 7: 251-263 (2005)

Metenier G, Driancourt MA, Cribiu EP: An XO chromosome constitution in a sterile mare. Ann Genet Sel Anim 11:161-163 (1979).

Ming R, Moore PH: Genomics of sex chromosomes. Curr Opin Plant Biol 10:123-130 (2007).

Miyake YI, Ishikawa T, Kawata K: Three cases of mare sterility with sex-chromosomal abnormality $(63, \mathrm{X})$. Zuchthygiene 14:145-150 (1979).

-Moreno-Millan M, Delgado Bermejo JV, Alonso Garcia F: X-trisomy in Friesian cow with continuous oestrus. Vet Rec 121:167-168 (1987).

Moreno-Millan M, Delgado Bermejo JV, Lopez Castillo G: An intersex horse with X chromosome trisomy. Vet Rec 124:169-170 (1989).

- Murphy WJ, Davis B, David VA, Agarwal R, Schäffer AA, et al: A 1.5-Mb-resolution radiation hybrid map of the cat genome and comparative analysis with the canine and human genomes. Genomics 89:189-196 (2007).

Nes N: Betydningen av kromosomaberrasjoner hos dyr. Forsku Fors Landbruket 19:393-410 (1968).

Nie GJ, Momont HW, Buoen LC: A survey of sex chromosome abnormalities in 204 mares selected for breeding. J Eq Vet Sci 13:456-459 (1993).

Norberg HS, Refsdal AO, Garm ON, Nes N: A case report on X-trisomy in cattle. Hereditas 82:69-72 (1976).

Ohno S: Sex Chromosomes and Sex-Linked Genes (Springer, Berlin 1967).

Oliver-Bonet M, Benet J, Martin RH: Studying meiosis: a review of FISH and M-FISH techniques used in the analysis of meiotic processes in humans. Cytogenet Genome Res 114:312-318 (2006).

-Olivier M, Breen M, Binns MM, Lust G: Localization and characterization of nucleotide sequences from the canine Y chromosome. Chromosome Res 7:223-233 (1999).

Page J, Berríos S, Parra MT, Viera A, Suja JA, et al: The program of sex chromosome pairing in meiosis is highly conserved across marsupial species: implications for sex chromosome evolution. Genetics 170:793-799 (2005).

Page J, Viera A, Parra MT, de la Fuente R, Suja JA, et al: Involvement of synaptonemal complex proteins in sex chromosome segregation during marsupial male meiosis. PLoS Genet 2:e136 (2006)

Palmer S, Perry J, Kipling D, Ashworth A: A gene spans the pseudoautosomal boundary in mice. Proc Natl Acad Sci USA 94:1203012035 (1997). 
Pathak S, Elder FF: Silver-stained accessory structures on human sex chromosomes. Hum Genet 54:171-175 (1980).

- Payne HW, Ellsworth K, DeGroot A: Aneuploidy in an infertile mare. J Am Vet Med Assoc 153: 1293-1299 (1968).

-Pearks Wilkerson AJ, Raudsepp T, Graves T, Albracht D, Warren W, et al: Gene discovery and comparative analysis of X-degenerate genes from the domestic cat Y chromosome. Genomics 92:329-338 (2008).

- Perry J, Ashworth A: Evolutionary rate of a gene affected by chromosomal position. Curr Biol 9:987-989 (1999).

- Perry J, Palmer S, Gabriel A, Ashworth A: A short pseudoautosomal region in laboratory mice. Genome Res 11:1826-1832 (2001).

$\checkmark$ Peterlin B, Kunej T, Hristovski D: Diagnostic test for Y chromosome microdeletion screening in male infertility. Genet Test 8:45-49 (2004).

Pinheiro LEL, Almeida IL, Garcia JM, Barsur PK: Trisomy X and 1/29 translocation in infertile heifers. Theriogenology 28:891-898 (1987).

Power MM: Chromosomes of the horse. Adv Vet Sci Comp Med 34:131-167 (1990).

- Power MM, Leadon DP: Diploid-triploid chimaerism $(64, \mathrm{XX} / 96, \mathrm{XXY})$ in an intersex foal. Equine Vet J 22:211-214 (1990)

-Prakash B, Balain DS, Lathwal SS: A 49, XO sterile murrah buffalo (Bubalus bubalis). Vet Rec 130:559-560 (1992).

-Prakash B, Balain DS, Lathwal SS, Malik RK: Trisomy-X in a sterile river buffalo. Vet Rec 134:241-242 (1994).

-Prakash B, Balai DS, Lathwal SS, Malik RK: Infertility associated with monosomy-X in a crossbred cattle heifer. Vet Rec 137:436-437 (1995).

Dritchard CA, Goodfellow PJ, Goodfellow PN: Mapping the limits of the human pseudoautosomal region and a candidate sequence for the male-determining gene. Nature 328: 273-275 (1987)

- Probst FJ, Cooper ML, Cheung SW, Justice MJ: Genotype, phenotype, and karyotype correlation in the XO mouse model of Turner Syndrome. J Hered 99:512-517 (2008).

Prothero KE, Stahl JM, Carrel L: Dosage compensation and gene expression on the mammalian X chromosome: one plus one does not always equal two. Chromosome Res 17: 637-648 (2009).

-Quilter CR, Blott SC, Mileham AJ, Affara NA, Sargent CA, Griffin DK: A mapping and evolutionary study of porcine sex chromosome genes. Mamm Genome 13:588-594 (2002).

Raudsepp T, Chowdhary BP: The horse pseudoautosomal region (PAR): characterization and comparison with the human, chimp and mouse PARs. Cytogenet Genome Res 121: 102-109 (2008).
Raudsepp T, Chowdhary BP: Cytogenetics and physical chromosome maps, in Rothschild MF, Ruvinsky A (eds): The Genetics of the Pig, pp 134-178 (CAB International, 2011).

Raudsepp T, Lee EJ, Kata SR, Brinkmeyer C, Mickelson JR, et al: Exceptional conservation of horse-human gene order on X chromosome revealed by high-resolution radiation hybrid mapping. Proc Natl Acad Sci USA 101:2386-2391 (2004a).

Raudsepp T, Santani A, Wallner B, Kata SR, Ren C, et al: A detailed physical map of the horse Y chromosome. Proc Natl Acad Sci USA 101: 9321-9326 (2004b).

Raudsepp T, Gustafson-Seabury A, Durkin K, Wagner ML, Goh G, et al: A 4,103 marker integrated physical and comparative map of the horse genome. Cytogenet Genome Res 122:28-36 (2008).

Rieck GW, Höhn H, Herzog A: X-trisomy in cattle with signs of familial disposition for meiotic disturbances [German]. Cytogenetics 9: 401-409 (1970).

-Ross MT, Grafham DV, Coffey AJ, Scherer S, McLay K, et al: The DNA sequence of the human X chromosome. Nature 434:325-337 (2005).

Sharp P: Sex chromosome pairing during male meiosis in marsupials. Chromosoma 86:2747 (1982).

Shiue YL, Millon LV, Skow LC, Honeycutt D, Murray JD, et al: Synteny and regional marker order assignment of 26 type I and microsatellite markers to the horse $\mathrm{X}$ - and Y-chromosomes. Chromosome Res 8:45-55 (2000).

Sigurdsson MI, Smith AV, Bjornsson HT, Jonsson JJ: HapMap methylation-associated SNPs, markers of germline DNA methylation, positively correlate with regional levels of human meiotic recombination. Genome Res 19:581-589 (2009).

Sinclair AH, Berta P, Palmer MS, Hawkins JR, Griffiths BL, et al: A gene from the human sex-determining region encodes a protein with homology to a conserved DNA-binding motif. Nature 346:240-244 (1990).

Skaletsky H, Kuroda-Kawaguchi T, Minx PJ, Cordum HS, Hillier L, et al.: The male-specific region of the human $\mathrm{Y}$ chromosome is a mosaic of discrete sequence classes. Nature 423:825-837 (2003)

- Smith FW Jr, Buoen LC, Weber AF, Johnston SD, Randolph JF, Waters DJ: X-chromosomal monosomy $(77, \mathrm{X} 0)$ in a Doberman Pinscher with gonadal dysgenesis. J Vet Intern Med 3: 90-95 (1989).

Stewart-Scott IA: Infertile mares with chromosome abnormalities. N Z Vet J 36:63-65 (1988)
Swartz HA, Vogt DW: Chromosome abnormalities as a cause of reproductive inefficiency in heifers. J Heredity 74:320-324 (1983).

-Switoński M, Godynicki S, Jackowiak H, Pieńkowska A, Turczuk-Bierla I, et al: X trisomy in an infertile bitch: cytogenetic, anatomic, and histologic studies. J Hered 91:149-150 (2000).

Tartaglia NR, Howell S, Sutherland A, Wilson R, Wilson L: A review of trisomy X (47,XXX). Orphanet J Rare Dis 5:8 (2010).

Taylor MJ, Trommershausen-Smith A: Equine karyotyping, in Proceedings of thelst International Symposium on Equine Hematology, Michigan, May 1975, pp 124-131.

Tibary A, Rodriguez J, Sandoval S: Reproductive emergencies in camelids. Theriogenology 70:515-534 (2008).

Trommershausen-Smith A, Hughes JP, Neely DP: Cytogenetic and clinical findings in mares with gonadal dysgenesis. J Reprod Fertil Suppl 271-276 (1979).

Tüttelmann F, Gromoll J: Novel genetic aspects of Klinefelter's syndrome. Mol Hum Reprod 16:386-395 (2010).

Urbach A, Benvenisty N: Studying early lethality of 45,XO (Turner's syndrome) embryos using human embryonic stem cells. PLoS One 4:e4175 (2009).

-Van Laere AS, Coppieters W, Georges M: Characterization of the bovine pseudoautosomal boundary: documenting the evolutionary history of mammalian sex chromosomes. Genome Res 18:1884-1895 (2008).

Villagómez DA, Pinton A: Chromosomal abnormalities, meiotic behavior and fertility in domestic animals. Cytogenet Genome Res 120: 69-80 (2008)

Villagómez DA, Parma P, Radi O, Di Meo G, Pinton A, et al: Classical and molecular cytogenetics of disorders of sex development in domestic animals. Cytogenet Genome Res 126: 110-131 (2009)

-Wade CM, Giulotto E, Sigurdsson S, Zoli M, Gnerre S, et al: Genome sequence, comparative analysis, and population genetics of the domestic horse. Science 326:865-867 (2009).

Yadav BR, Balakrishnan CR: Trisomy of the X chromosome in a Murrah buffalo. Vet Rec 111:184-185 (1982).

- Yadav BR, Kumar P, Tomer OS, Kumar S, Balain DS: Monosomy X and gonadal dysgenesis in a buffalo heifer (Bubalus bubalis). Theriogenology 34:99-105 (1990).

Young AC, Kirkness E., Breen M: Tackling the characterization of canine chromosomal breakpoints with an integrated in-situ/insilico approach: the canine PAR and PAB. Chromosome Res 16:1193-1202 (2008).

-Zartman DL, Hinesley LL, Gnatkowski MW: A 53,X female sheep (Ovis aries). Cytogenet Cell Genet 30:54-58 (1981). 